Wioletta Kamińska, Mirosław Mularczyk

Institute of Geography, Jan Kochanowski University

E-mail: wioletta.kaminska@pu.kielce.pl

\title{
DEVELOPMENT AND DISTRIBUTION OF PRIVATE MICROFIRMS IN MID-SIZE POLISH TOWNS DURING THE TRANSFORMATION PERIOD
}

\begin{abstract}
The objective of the paper is to present the development and distribution of microfirms in mid-size Polish towns during the years of transformation of the political system. Research comprised towns with a population numbering from 20 thousand to 100 thousand inhabitants. According to the Central Office of Statistics reporting standards it is recognized that micro enterprises are economic entities employing up to nine people. Research has shown that a dynamic growth of microfirms took place during the transformation period in mid-size Polish towns. Majority of them came into being in towns with high tourism values located near border crossing points, along the main communication routes, on the edge of great urbanindustrial agglomerations and towns located within special economic zones. On the other hand, the least number of microfirms were recorded in towns with less than 50 thousand inhabitants, usually peripherally located in a given voivodship.
\end{abstract}

Key words: microfirms, mid-size towns, economic transformation, ownership and size structure of economic entities.

\section{INTRODUCTION}

In Poland, transformation of the political system led to radical changes of the social, economic and spatial structures created under conditions of centrally managed economy (Stryjakiewicz 1999, Zioło 1999). The ownership and size structure of economic entities underwent a particular transformation. Until 1989, the ownership structure in Poland was absolutely dominated by the so-called national sector and the size structure was characterized by a majority of large enterprises and underdevelopment of small and mid-size enterprises.

The transformation of the political system was based, among others, on the assumption that ownership changes towards a greater participation of the private sector will increase effectiveness of the economy and will facilitate its growth. Thus, already during the years 1988-1990, the legal basis for privatization of national enterprises and the development of new private 
economic entities were created. As consequence, during the years 1988-2003, participation of the private sector in the employment structure increased from $7 \%$ to $70 \%$ and in global production from $5 \%$ to $77.1 \%$. Also, significant changes occurred in the size structure of economic entities. In 2003, small enterprises (not exceeding 50 employees) amounted to $99 \%$ of the total number of economic entities.

The political transformation process took place with a different temporal and spatial intensity. Individual settlement units were characterized by different susceptibility levels of accepting new management principles. Large towns and cities relatively easily adapted to new economic conditions. This was due to historically formed competitiveness of geographic and economic locations, infrastructural conditions (Dunford, Benko 1991, Krätke 1991, Kołodziejski 2000) and qualified work market, specialized services market and an especially innovative environment (Veltz 1991). In most of the midsize towns, however, the economic situation was decisively unfavorable. Liquidation of national industrial enterprises which in many towns were the main employee of the local population led to a quick growth of unemployment. Poorly developed, the remaining sectors of the economy could not absorb the ever growing unemployed masses. Additionally, following territorial reform of 1999, numerous towns lost their administrative functions. In consequence, unemployment increased, financial resources for development were limited and many towns began to slowly degrade. Quickly, it became visible that new employment opportunities arose mainly in small private companies.

The following question should be asked: how did the new economic conditions influence the small company development process in mid-size Polish towns?

Taking under consideration the issues discussed above, the objective of this paper is the presentation of development and distribution of small private companies in mid-size Polish towns during transformation of the political system. Due to the availability of statistical data, the reference period comprises the years $1994-2003$. Research concentrated on all towns with a population from 20 thousand to 100 thousand inhabitants. In 1994, this set amounted to 189 towns and in 2003 it numbered 181. The analysis was limited to the smallest non-agrarian economic entities which employed not more than nine persons. They amounted to $96 \%$ of the country's total economic entities and according to the classification of the Central Office of Statistics are identified as microfirms.

\section{INFORMATION SOURCES AND RESEARCH METHODS}

Data on the number of microfirms registered in the REGON system in the town pattern made available by the Central Office of Statistics were used in this article. Currently, it is the only national scale source. Because of numerous opinions that the system is incomplete and the given informa- 
tion is partially out of date, the REGON data were compared with data from tax offices. In 2003, according to the REGON system, $2.8 \mathrm{ml}$ such companies operated in Poland. However, according to tax offices their number was $2.4 \mathrm{ml}$. This means that the REGON data surpass by $16.6 \%$ the tax office numbers. This fact prescribes caution in research proceedings. Nevertheless, the number of entities in the REGON gives testimony as to the activeness of undertaking entrepreneurial initiatives, the intensity of operations in this area and therefore this data should not be underestimated (Glikman 2000).

The scope of the methods comprises the fundamental statistical indices, including the entrepreneurship index indicating the number of small firms per 1000 inhabitants, company number growth indices in 1994-2003 and the localization quotient counted as the percentage ratio of towns participating in the number of small private firms in the country to the towns participating in the overall population number in Poland. The location quotient may be regarded as a relationship measure (excess-scarcity) of microfirms in regard to the population (Stryjakiewicz, 1999). Cartodiagrams were used to present the distribution of microfirms in 1994-2003.

\section{CHANGES IN THE NUMBER OF MICROFIRMS IN MID-SIZE TOWNS IN POLAND IN 1994-2003}

During the years 1994-2003, the number of microfirms in mid-size towns increased from 242.7 thousand to 617 thousand, i.e. by $254 \%$. The growth rate was greater than the average for Polish towns (233.4\%) and for large towns $(234 \%)$ but smaller than for the smallest towns (Tab. 1.).

Table. 1.

Changes in the number of microfirms in mid-size towns in Poland in 1994-2003

\begin{tabular}{|c|c|c|c|c|c|c|c|c|c|}
\hline \multirow{3}{*}{$\begin{array}{l}\text { Towns } \\
\text { according } \\
\text { to size } \\
\text { (number of } \\
\text { inhabitants) }\end{array}$} & \multicolumn{4}{|c|}{1994} & \multicolumn{4}{|c|}{2003} & \multirow{3}{*}{$\begin{array}{l}\text { Microfirm } \\
\text { dynamics } \\
\text { index (\%) } \\
1994=100\end{array}$} \\
\hline & \multirow{2}{*}{ 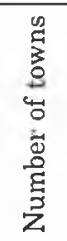 } & \multicolumn{2}{|c|}{$\begin{array}{c}\text { Structure } \\
(\%)\end{array}$} & \multirow[b]{2}{*}{ 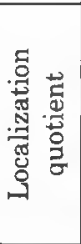 } & \multirow{2}{*}{ 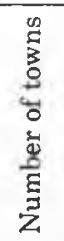 } & \multicolumn{2}{|c|}{$\begin{array}{c}\text { Structure } \\
(\%)\end{array}$} & \multirow{2}{*}{ 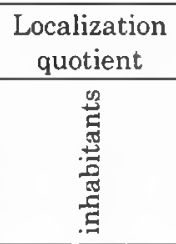 } & \\
\hline & & 异莒 & 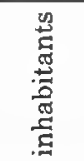 & & & 岛 苞 & 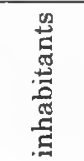 & & \\
\hline $\begin{array}{l}\text { small } \\
(<20 \mathrm{~K})\end{array}$ & 629 & 16,3 & 19,5 & 0,84 & 662 & 19,4 & 20,8 & 0,93 & 227,0 \\
\hline $\begin{array}{l}\text { average } \\
(20-100 \mathrm{~K})\end{array}$ & 189 & 27.5 & 31,9 & 0,86 & 181 & 29,9 & 31,4 & 0,95 & 254.0 \\
\hline $\begin{array}{l}\text { large } \\
(>200 \mathrm{~K})\end{array}$ & 42 & 56,2 & 48,6 & 1,16 & 40 & 50,7 & 47,8 & 1,06 & 234,1 \\
\hline Total & 860 & 100 & 100,0 & $x$ & 883 & 100,0 & 100,0 & $x$ & 233,4 \\
\hline
\end{tabular}

Source: Central Office of Statistics Yearbooks for 1995-2004. 
High dynamics influenced the growth of significance of mid-size towns in the structure of microfirms operating in all towns. Their share increased from $27.5 \%$ to $29.9 \%$ (Tab. 1.) The localization quotient increased somewhat from 0.86 to 0.95 (Tab.1) but it still was less than 1, which indicates a scarcity of microfirms in reference to the population number inhabiting mid-size towns.

\section{CHANGES IN DISTRIBUTION OF MICROFIRMS IN MID-SIZE TOWNS IN POLAND DURING THE YEARS OF POLITICAL SYSTEM TRANSFORMATION}

In 1994, majority microfirms (from 3000 to 4999 ) were located in eleven towns which gathered $7.9 \%$ of the total number of such companies operating in mid-size towns as well as $6.1 \%$ inhabitants of towns of this size (Tab. 2 . Fig. 1). The enterprise index was 54.6 and was higher than the average for Polish towns (31.9). This group was mainly comprised of settlement units located along communication routes connecting border crossing points with large Polish socio-economic centers, e.g. Jelenia Góra, Stargard Szczeciński, Świnoujście, Chełm (Fig. 1). On this basis, it may be assumed that development of the smallest economic entities was related to the opening of national borders for an influx of people and products, development of crossborder commerce and tourism oriented services.

Table. 2.

Changes in the spatial structure of microfirms in mid-size towns in Poland in 1994-2003

\begin{tabular}{|c|c|c|c|c|c|c|c|c|}
\hline \multirow[b]{3}{*}{$\begin{array}{l}\text { Number of } \\
\text { microfirms } \\
\text { (sectors) }\end{array}$} & \multicolumn{4}{|c|}{1994} & \multicolumn{4}{|c|}{2003} \\
\hline & \multirow{2}{*}{ 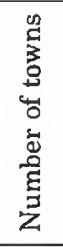 } & \multicolumn{2}{|c|}{ Share (\%) } & \multirow{2}{*}{ 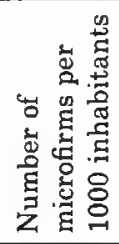 } & \multirow{2}{*}{ 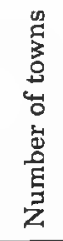 } & \multicolumn{2}{|c|}{ Share (\%) } & \multirow[b]{2}{*}{$\begin{array}{c}\text { Number of } \\
\text { microfirms per } \\
1000 \text { inhabitants }\end{array}$} \\
\hline & & 总 & 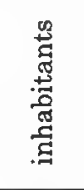 & & & 号骂 & 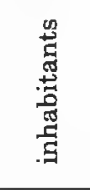 & \\
\hline$<999$ & 90 & 25,3 & 26,4 & 24,2 & . & - & - & - \\
\hline $1000-1999$ & 73 & 43,3 & 43,2 & 32,0 & 34 & 8,9 & 11,0 & 67,8 \\
\hline $2000-2999$ & 15 & 14,3 & 14,4 & 34,0 & 61 & 24,9 & 25,1 & 82,8 \\
\hline $3000-4999$ & 11 & 17,1 & 16,0 & 54,6 & 56 & 35,4 & 35,3 & 83,2 \\
\hline 5000-6999 & - & - & - & $\cdot$ & 24 & 22,9 & 22,5 & 84,2 \\
\hline $7000-10999$ & - & - & - & - & 6 & 7,9 & 6,1 & 108,7 \\
\hline Total & 189 & 100,0 & 100,0 & 31,9 & 181 & 100,0 & 100,0 & 83,3 \\
\hline
\end{tabular}

Source: Central Office of Statistics Yearbooks for 1995-2004.

The second group comprised fifteen towns where from 2000 to 2999 of the analyzed economic entities were located. In total, they included $14.3 \%$ of the 
microfirms located in mid-size towns and $14.4 \%$ of the inhabitants (Tab. 2). The entrepreneurship index was lower than in the previous group and amounted to 34.0 (Tab.2). It included, above all, towns with clearly defined functions: administrative (capitals of the then voivodeships: Ostroleka, Konin, Ciechanów, Piotrków Trybunalski), tourism (Sopot, Kołobrzeg, Inowrocław) and industrial (Wodzisław Śląski, Jaworzno, Siemianowice, Bełchatów, Kędzierzyn Koźle) (Fig. 1).

In 1994 there was a majority of mid-size companies, with the smallest number of microfirms (up to 1000). This group comprised ninety towns which gathered in total $25.3 \%$ of the microfirms operating in mid-size towns and $26.4 \%$ of the inhabitants of towns of this size.

During the years 1994-2003 the number of microfirms increased in all the mid-size towns. The growth index oscillated from 1.3 to 8.1 (Tab. 2). Diversity of the dynamics influenced the change of the spatial structure in the analysed timeframe.

In 2003, majority of the companies operated in the following six towns: Słupsk, Jelenia Góra, Kołobrzeg, Ostrów Wielkopolski, Gniezno, Pabianice (Tab. 2., Fig. 2.). In each of them, 7-11 thousand private microfirms were registered. The entrepreneurship index, on the average, was 108.7 , whereas in Polish towns it was 87.4.

Subsequent twenty four towns, where from 5 to 7 thousand of the examined economic entities functioned had a high number of microfirms. The entrepreneurship index was 84.2 (Tab. 2.). The thirty discussed towns had a dominating significance in the microfirm structure and gathered, in total, over $30 \%$ of the overall number of small companies located in mid-size towns and $28.6 \%$ of the population of towns with this population size. Among them were those:

- distinguishing themselves by high tourism values (Słupsk, Kołobrzeg, Jelenia Góra, Świnoujście) (Fig.2.). The microfirm development was related here to broadly understood tourism oriented services (accommodations rental, small catering, production and sale of souvenirs, parking facilities, etc.),

- located near border crossing points, alongside roads leading from the border inland, e.g. Zamość, Chełm, Stargard Szczeciński, Świnoujście) (Fig. 2.). Here, development of microfirms is linked to services on behalf of cross-border commerce and tourism.,

- located close to the largest urban and industrial agglomerations: Warsaw: (Legionowo, Pruszków), Łódz (Pabianice, Zgierz), Poznań (Gniezno) (Fig. 2.). These cities have taken advantage of their attractive to business locations (large markets for merchandise in the not distant agglomeration and at the same time possibility for reducing operational costs stemming from lower rental and municipal services costs than in large cities. Furthermore, they usually have a better developed technical infrastructure necessary for the development of private entrepreneurship than it may be found in other settlement units (Makieła 1998, Komornicki 1999), 


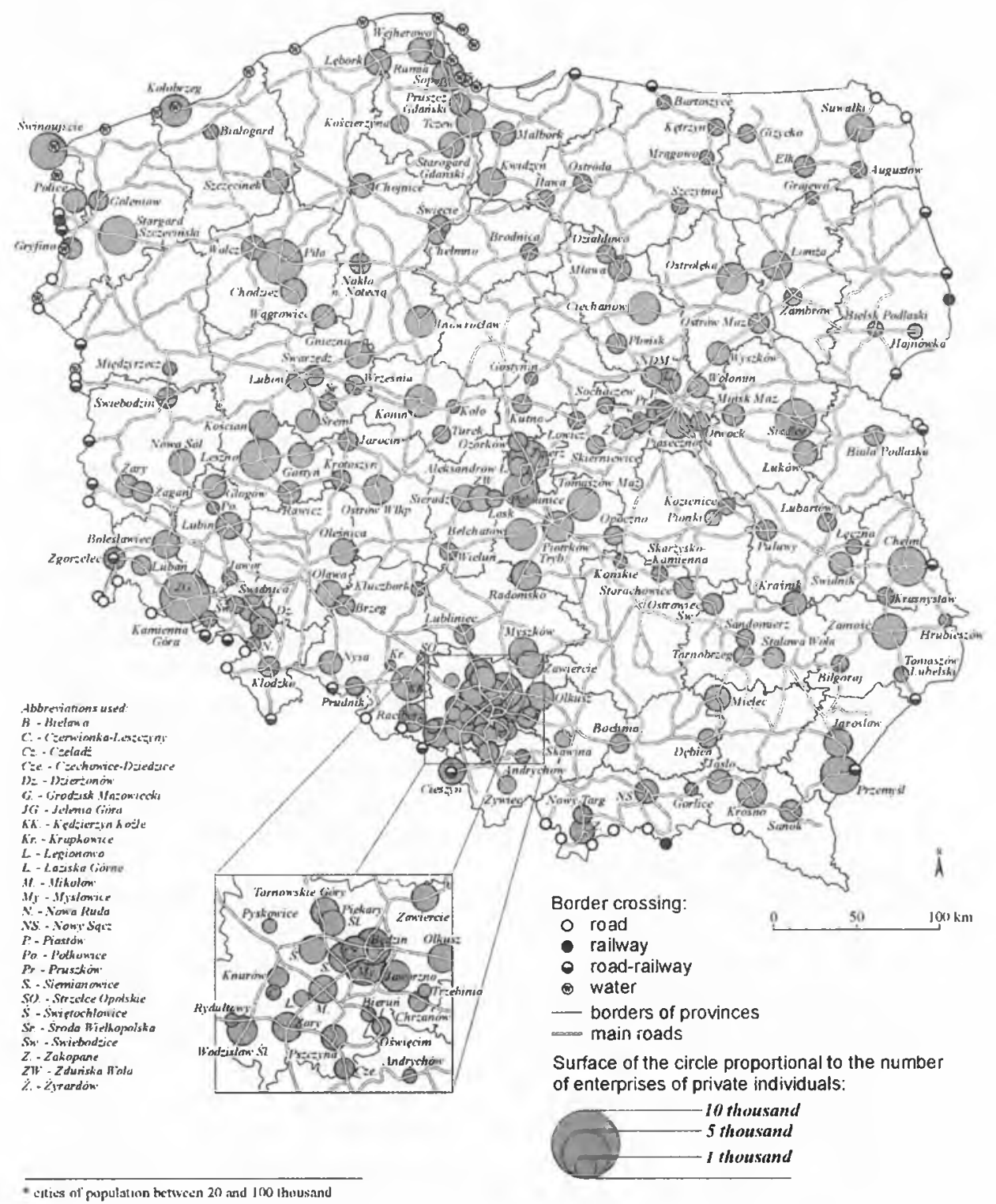

Fig. 1. Distribution of private microfirms in mid-size polish towns in 1994 


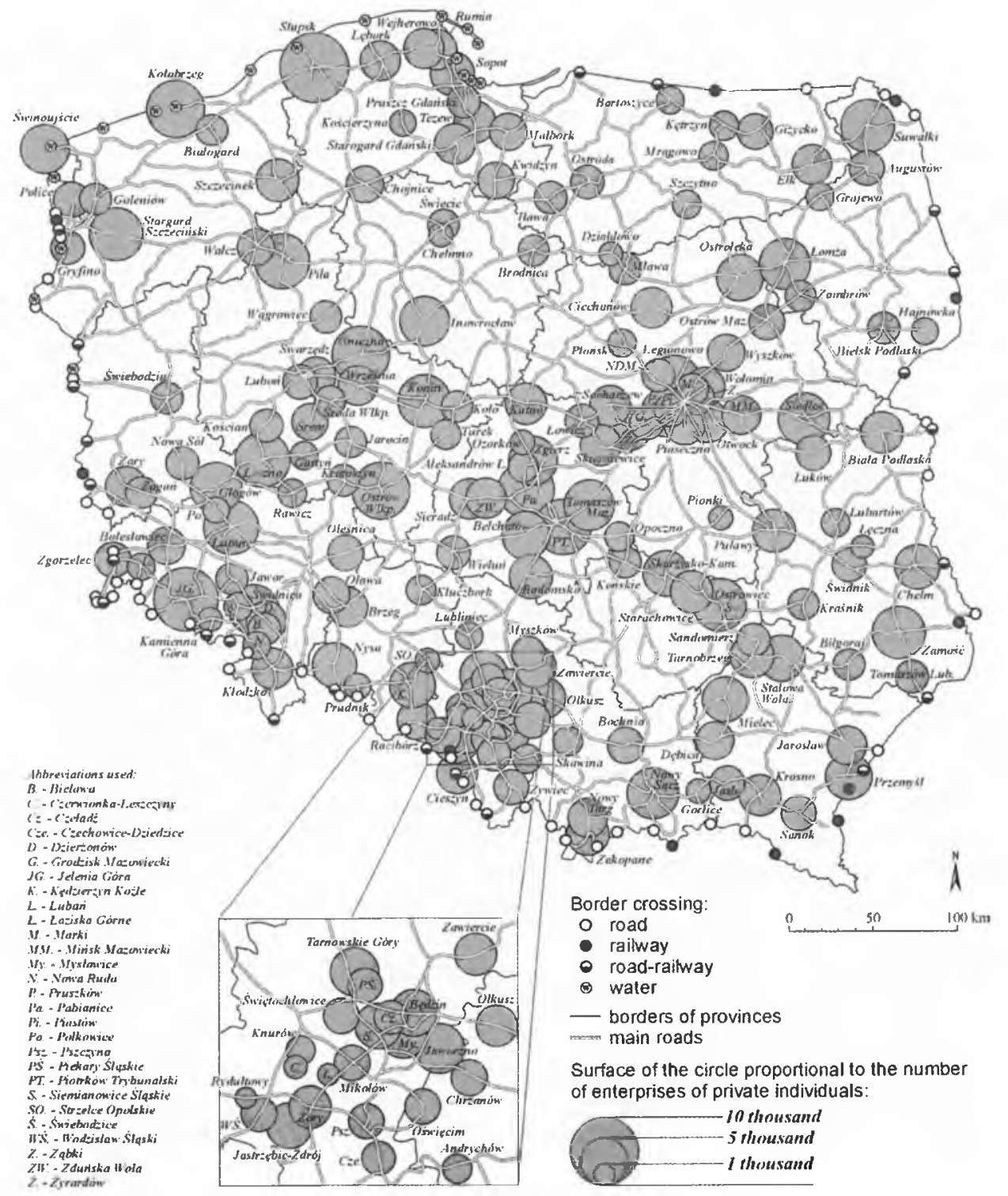

- cilies of ponpulation between 20 and 100 thesusand

Fig. 2. Distribution of private microfirms in mid-size polish towns in 2003 
- located in the special economic zone areas, where business operations may be related with tax relieves (Suwałki, Ostrowiec Św., Pabianice, Zgierz) (Fig. 2.),

- having dynamic local self-governments (Piaseczno, Kołobrzeg, Świnoujście, Lubin) (fig. 2.). They belong to the so-called "golden one hundred leaders of local development" (Surażska 2001) and are in the group of spatial units with the greatest level of investments on the national level,

- having, till 1999, the status of voivodeship capital towns (Jelenia Góra, Piotrków Tryb., Piła, Suwałki, Siedlce, Konin, Łomża) (Fig. 2.). Favorable to the development of microfirms in theses settlement units is the relatively well developed technical infrastructure. Often, building facilities earlier used by the voivodeship authorities were adapted to serve as incubators of entrepreneurship. In theses towns, there also are numerous other institutions supporting small scale entrepreneurship (Dębski 2002),

- where locally or in their vicinity operate large industrial plants (Bełchatów, Lubin, Głogów) (Fig. 2). Here, microfirms develop by cooperating with large enterprises.

In 2003, most numerous were those towns in which from one thousand to four thousand microfirms were operating. This group was represented by 94 settlement units, gathering $1 / 3$ of the total number of microfirms located in mid-size towns and $36.1 \%$ inhabitants of these towns. The entrepreneurship index was 78.2 and was decisively lower than the mean index for mid-size towns as well as for all towns in Poland (Tab.2.). All of theses towns, with the exception of Piekary Ślaskie and Świętochłowice, had fewer than fifty thousand inhabitants. Of interest is the fact that within this group there were as many as eight towns from the Ślaskie Voivodeship (Piekary Ślaskie, Knurów, Świętochłowice, Wodzisław Śląski, Czechowice-Dziedzice, Czeladż, Mikołów oraz Żywiec) (Fig.2.). Z. Rykiel (1997) recognized this area as part of the deteriorated areas and stated that it is intensely dependent on heavy industry and coal mining and the employment market is not functionally diversified. This is an area which, according to T. Stryjakiewicz (1999), relatively easily went through the "transformation shock" and continuous to maintain a high position in the economic structure. This privileged position of the Slaskie Voivodeship, with costly and of limited efficiency restructuring programs, high remunerations in the mining sector and a low unemployment rate all together are no encouragement to undertake the risk of self-employment.

\section{CONCLUSIONS}

1. During transformation of the political system, microfirms became an important element of activating the economy of mid-size towns and mitigat- 
ing the social consequences of transformation throughout the country. During the years 1988-2003 almost all of the new workplaces were created in the private sector, including microfirms. In 2003, in mid-size towns there were almost 617 thousand microfirms. Taking into account the fact that, on the average, two persons are employed by such firms (Kamińska 2004), they created over 1.2 million workplaces. A both economically and psychologically positive phenomenon of "self-employment" came into being.

2. Particular mid-size towns in different fashion reacted to the new management conditions and the development of private enterprise. This was expressed by highly diversified dynamics of the number of microfirms. The dynamics index oscillated between $128 \%$ and $811 \%$.

3 . Towns attracting a great number of tourists were most active in the development of microfirms. However, not all mid-size towns attractive to tourists had a higher microfirm concentration. This was caused by underdevelopment of a tourism infrastructure and insufficient promotion of the area.

4. A low number of microfirms was observed in towns of the Slaskie Voivodeship. The protective national policy of this region of Poland was the decisive reason for its slow entrance into new, competitive relationships.

5 . A relatively low potential of microfirms was noted in the smallest towns of the examined group (not exceeding fifty thousand inhabitants).

6. Modifications of the spatial structure were caused by different degrees of attractiveness of particular towns in regard to locating microfirms.

7. It was confirmed that institutional factors such as tax and investment relieves in special economic zones influence the development of microfirms.

8. Activities of local authorities had a significant influence on the growth of private entrepreneurship.

9. Further development of microfirms in mid-size towns will depend, above all, upon the government's policy toward the small enterprise sector and the conditions stemming from Poland's accession to the European Union. Not without meaning remain the country's demographic changes.

10. A positive recognition of functioning of microfirms in various spatial arrangements and possible development tendencies will allow local authorities and central government structures to elaborate favorable conditions for the development of small private enterprises. It is of special significance in mid-size towns where, in 2003, on the average, microfirms constituted $85 \%$ of the total number of economic entities (in 1994 it was $76,8 \%$ ).

\section{REFERENCES}

Dębski J., 2002, Lokalne bieguny wzrostu $w$ Polsce na przetomie XX $i$ XXI wieku [Local growth poles in Poland at the turn of the $\mathrm{XX}^{\text {th }}$ and XXI ${ }^{\text {st }}$ centuries; in Polish], Wyd. WSFiZ Białystok.

D u n f ord M., B enko G., 1991, Neo-Fordism or post-Fordism?. Some conclusion and further remarks, [in:] G. Benko, M. Dunford (eds), Industrial change and regional development, London. 
Glik m a n P., 2000, Zmiany strukturalne w sektorze malych i średnich przedsiębiorstw (MSP) w latach 1990-1998 [Structural changes in the small and mid-size enterprise sector in 1990-1998; in Polish], [in:] A. Lipowski (ed.), Struktura gospodarki transformujacej się, Wyd. „Zigguart” Warszawa.

Ka m ińs k a W., 2004, Kształtowanie się pozarolniczej indywidlualnej dziatalności gospodarczej $w$ Polsce $w$ latach 1988-2003 [Development of extra-agrarian individual economic activity in Poland in 1988. 2003; in Polish] (in print).

Kołodziejski J., 2000, Koncepcja transformacji systemu planowania strategicznego rozwoju miast i regionów w świetle reformy terytorialnej organizacji państwa [Concept of transformation of the strategic planning system of urban and regional development in view of the territorial reform of the state organisation; in Polish], Biuletyn KPZK PAN, 192, Warszawa.

Komornicki T., 1999, Wschodnia Strefa Aktywności Gospodarczej w krajowej i kontynentalnej sieci transportowej (Dynamika układów komunikacyjnych, przejścia graniczne, ruch tranzytowy [Eastern economic activity zone in national and continental transport networks (Dynamics of communication layouts, border cross points, transit movement); in Polish] [in:] R. Horodeński, M. Rościszewski (ed.), Wschodnia Strefa Aktywności Gos. podarczej, Wyd. WSE, Białystok.

K rätk e S., 1991, Cities in transformation: the case of West Germany, [in:] G. Benko, M. Dunford (eds) Industrial change and regional development, London.

M a kieła Z., 1998, Infrastruktura techniczna $w$ strukturze regionalnej Polski potudniowowschodniej [Technical infrastructure in the structure of regional south- eastern Poland; in Polish], Wyd. Naukowe AE, Katowice.

Rykiel Z., 1997, Relacje centrum-peryferie w Polsce w warunkach transformacji ustrojowej [The center-peripheries relationship in Poland under conditions of political transformation; in Polish], [in:] Kukliński A., (ed.) Problemalyka przestrzeni europejskiej, Europejski Insty. tut Rozwoju Regionalnego i Lokalnego, UW, Warszawa.

Stryjakiewicz T., 1999, Adaptacja przestrzenna przemyslu $w$ Polsce $w$ warunkach transformacji [Spatial adaptation of industry in Poland during the transformation; in Polish], Wyd. Nauk. UAM Poznań.

Surażska W., 2001, Przedsiębiorczość słabo wynagradzana [Poorly remunerated entrepreneurship; in Polish], Rzeczpospolita, 27.11.2001.

Veltz P., 1991, New models of production organisation and trends in spatial development, [in:] G. Benko, M. Dunford (eds), Industrial change and regional development, London.

$\mathrm{Z}$ i o 1 o Z., 1999, Transformacja struktur subregionalnych Polski poludniowo-wschodniej $w$ okresie zmian systemu gospodarowania [Transformation of sub-regional structures in southeastern Poland during changes of the economic system; in Polish], Wyd. PAN Kraków.

English translation: Malgorzata Milaszewska 